\title{
Protracted glucose fall in subcutaneous adipose tissue and skeletal muscle compared with blood during insulin-induced hypoglycaemia
}

\author{
E. Moberg, E. Hagström-Toft, P. Arner, J. Bolinder \\ Department of Medicine, Huddinge Hospital, Karolinska Institute, Stockholm, Sweden
}

\begin{abstract}
Summary The absolute glucose concentrations in subcutaneous adipose tissue and skeletal muscle were determined with microdialysis in 10 normalweight, healthy subjects during a standardized hyperinsulinaemic hypoglycaemic clamp. The concentration of tissue dialysate glucose was measured in 15 min fractions and compared with that in arterialized venous plasma. Insulin $\left(0.15 \mathrm{U} \cdot \mathrm{kg}^{-1} \cdot \mathrm{h}^{-1}\right)$ was infused i.v. to lower the plasma glucose level to $2.5 \mathrm{mmol} / \mathrm{l}$ over $30 \mathrm{~min}$. This level was maintained for $30 \mathrm{~min}$ by using a variable glucose infusion. Thereafter, the insulin infusion was stopped and the plasma glucose level was gradually increased to baseline levels over 120 min. During a $60-\mathrm{min}$ basal period, the glucose levels in muscle were $0.6 \mathrm{mmol} / \mathrm{l}$ lower than those in plasma $(p=0.002)$, whereas the levels in adipose tissue and plasma were similar. The glucose nadirs in muscle $(1.6 \pm 0.1 \mathrm{mmol} / \mathrm{l})$ and adipose tissue $(2.0 \pm$
\end{abstract}

$0.1 \mathrm{mmol} / \mathrm{l})$ were significantly lower than that in plasma $(2.4 \pm 0.1 \mathrm{mmol} / \mathrm{l})(p=0.001$ and 0.02 , respectively), and the time-to-nadir was substantially longer in muscle (69 $\pm 5 \mathrm{~min})$ and adipose tissue $(57 \pm 2 \mathrm{~min})$ than in plasma $(39 \pm 3 \mathrm{~min})(p=0.0004)$. When the insulin infusion was stopped, the increases in adipose tissue and muscle glucose concentrations were delayed by approximately 25 and $45 \mathrm{~min}$, respectively, as compared to the increase in plasma glucose. Thus, it seems that glucose measurements in adipose tissue and muscle more adequately reflect overall tissue homeostasis than do measurements in blood and that clinically relevant tissue glucopenia may be overlooked by conventional blood glucose measurements. [Diabetologia (1997) 40: 1320-1326]

Keywords Hypoglycaemia, insulin, carbohydrate metabolism, microdialysis, tissue blood flow.
Self-monitoring of blood glucose (SMBG) has become an important instrument in the management of intensified insulin therapy in patients with insulin-dependent diabetes mellitus (IDDM). Thus, insulin doses can be adjusted by the patients to meet their varying needs during everyday conditions and both hyper- and hypoglycaemia can be detected and adequately treated or even avoided. However, most patients find it

Received: 21 January 1997

and in final revised form: 2 July 1997

Corresponding author: Erik Moberg, M.D., Department of Medicine, Huddinge Hospital, S-14186 Huddinge, Sweden Abbreviations: SMBG, Self-monitoring of blood glucose; IDDM, insulin-dependent diabetes mellitus; BMI, body-mass index; CV, coefficient of variation; ANOVA, analysis of variance difficult to perform SMBG frequently enough to avoid hyper- and hypoglycaemia. Furthermore, clinically significant glucose fluctuations are sometimes not detected by SMBG [1]. To overcome this problem, methods for continuously monitoring the glucose concentration have been introduced in recent years. One of the most promising is the microdialysis technique [2]. The general principle underlying this technique is to mimic the function of a blood vessel by slowly perfusing a dialysis tube implanted in the tissue. The glucose concentration in the outgoing dialysate is determined and reflects the corresponding level in the extracellular fluid because of diffusion of glucose across the semipermeable membrane. This technique has shown that the glucose concentration in the subcutaneous adipose tissue is almost identical with that in the blood [3, 4]. In one study, continuous glucose measurements by 
the microdialysis technique resulted in a better resolution of glucose fluctuations than did conventional monitoring of blood glucose [5].

Most microdialysis studies of the glucose concentration in adipose tissue have been performed during euglycaemia or hyperglycaemia and hitherto no detailed studies during hypoglycaemia have been performed. Nor is there much knowledge about the glucose concentration in tissues other than fat in humans. Muscle measurements have been reported in two studies $[6,7]$. In these studies, glucose levels in skeletal muscle were shown to be significantly lower than those in blood. However, tissue glucose levels were calculated by indirect methods and no measurements during hypoglycaemia were presented.

The aim of the present study was therefore to measure the absolute glucose concentration in subcutaneous adipose tissue and in skeletal muscle in non-diabetic subjects before, during and after hypoglycaemia by using the microdialysis technique. Hypoglycaemia was induced by a standardized hyperinsulinaemic hypoglycaemic clamp. In addition, local blood flow in adipose tissue and muscle was measured by the ethanol perfusion technique.

\section{Subjects and methods}

Subjects. We studied 11 (5 female) healthy, drug-free subjects on 1-2 occasions. They were not obese (BMI $23.4 \pm 0.7 \mathrm{~kg} / \mathrm{m}^{2}$, range $20.6-27.3 \mathrm{~kg} / \mathrm{m}^{2}$ ) and their mean age was $27.0 \pm 1.1$ (range $21-35)$ years. The study was approved by the ethics committee of Huddinge Hospital. The subjects were given a detailed description of the experiment and their consent was obtained.

Microdialysis device. The microdialysis probe (CMA/60, CMA Microdialysis AB, Stockholm, Sweden) has been described in detail [8]. Briefly, a dialysis tube $(30 \times 0.5 \mathrm{~mm}, 20000 \mathrm{molecu}-$ lar weight cut-off) was glued to the end of a double-lumen cannula. The inlet lumen of the probe was connected to a highprecision perfusion pump (CMA/100 microinjection pump, CMA Microdialysis AB) and the probe was continuously perfused with a sterile solution. The perfusion solvent entered the probe through the outer cannula, streamed to the tip of the probe, and left the probe through the inner cannula, from which it was collected.

Study protocol. The subjects were examined in the supine position in the morning after an overnight fast. A teflon catheter used for blood sampling was inserted in a dorsal hand vein and the hand was kept in a warm box $\left(60-70^{\circ} \mathrm{C}\right)$ to ensure arterialization of the venous blood [9]. Another catheter was placed in the contralateral brachial vein and used for insulin and glucose infusions. In 10 subjects, one microdialysis probe was inserted into the subcutaneous tissue in the periumbilical region of the abdomen and another into the calf muscle. These probes were continuously perfused at a low velocity $(0.3 \mu \mathrm{l} /$ min). Ringer's solution (Apoteksbolaget, Umeå, Sweden: sodium $147 \mathrm{mmol} / 1$, potassium $4 \mathrm{mmol} / \mathrm{l}$, calcium $2.3 \mathrm{mmol} / 1$, chloride $156 \mathrm{mmol} / \mathrm{l}$ ) was used as the basal dialysate perfusion fluid. In 8 of the subjects, one additional probe in the abdominal subcutaneous tissue and another in the calf muscle were inserted and perfused at a higher velocity, i.e. $2 \mu \mathrm{l} / \mathrm{min}$. In four of the subjects, two extra probes, one in the abdominal fat and one in the calf muscle, were inserted and perfused with Ringer's solution to which glucose had been added ( $1 \mathrm{mmol} / 1$; perfusion velocity $0.3 \mu \mathrm{l} / \mathrm{min}$ ).

Changes in the local blood flow in the tissue surrounding the probes in adipose tissue and muscle were determined by the ethanol perfusion technique [10]. Two additional probes (one in adipose tissue and one in calf muscle) were perfused by an ethanol-containing solution $(2 \mu \mathrm{l} / \mathrm{min})$. Since ethanol is not locally degraded the ratio out/in of this flow-marker reflects changes in the nutritive blood flow, as discussed in detail [11].

In addition, the recovery of glucose in adipose tissue and muscle was assessed by an isotopic method [12]. This method is based on the premise that the recovery of a substance is equal in both directions across the dialysis membrane and that the tissue concentration of the radiolabelled marker is not influenced by the local blood flow [2]. Thus, a radioactive isotope ([U- $\left.{ }^{14} \mathrm{C}\right]$ glucose) (Amersham Sweden AB, Solna, Sweden) was added to the perfusion fluid, yielding a preparation of approximately $2500 \mathrm{cpm} / \mu \mathrm{l}$. The radioactivities (cpm) of the perfusate and the dialysate were determined. The relative loss of labelled glucose across the dialysis membrane from the perfusion fluid into the dialysed tissue is assumed to equal the flux of glucose from the tissue into the perfusion fluid (recovery). It is calculated as

$\frac{100 \times\left(\mathrm{cpm}_{\text {in }}-\mathrm{cpm}_{\text {out }}\right)}{\mathrm{cpm}_{\text {in }}}$

where $\mathrm{cpm}_{\mathrm{in}}$ is the radioactivity in the perfusion fluid and $\mathrm{cpm}$. out is the radioactivity in the dialysate fractions. In order to investigate the influence of possible changes in local blood flow on the determinations of glucose recovery, the probes were perfused with Ringer's solution alone or with the addition of the vasodilating agent hydralazine hydrochloride $(0.125 \mathrm{~g} / \mathrm{l})$ (Ciba-Geigy AG, Basel, Switzerland).

The distance between each probe was $3-5 \mathrm{~cm}$. Local skin anaesthesia (EMLA, Astra, Södertälje, Sweden) was used before cannulating the skin.

The hypoglycaemia experiment was started after a $60-\mathrm{min}$ period of basal sampling. Hypoglycaemia was then induced by a continuous i.v. insulin infusion $\left(0.15 \mathrm{U} \cdot \mathrm{kg}^{-1} \cdot \mathrm{h}^{-1}\right)$ aiming at reaching a plasma glucose level of approximately $2.5 \mathrm{mmol} / 1$ after $30 \mathrm{~min}$. This plasma level was maintained for $30 \mathrm{~min}$ by using a variable glucose $(20 \%)$ infusion. Thereafter, the insulin infusion was stopped and the glucose infusion was gradually reduced, so that a standardized increase of plasma glucose levels was obtained during $120 \mathrm{~min}$.

The glucose concentrations in the tissue dialysate were measured in 15-min fractions during the entire experiment and compared with those in the arterialized plasma samples obtained in the middle of each 15 -min fraction taking account of a 10-min delay for the flow of the dialysate through the outgoing catheter. Ethanol concentrations in the dialysate were measured in 15 -min fractions and ${ }^{14} \mathrm{C}$-glucose levels were assessed in 30-min fractions.

During hypoglycaemia, plasma samples were taken for determining the levels of free insulin and catecholamines at $22.5,-7.5,22.5,37.5,52.5,67.5$ and $112.5 \mathrm{~min}$, the insulin infusion starting at $0 \mathrm{~min}$.

Analytical methods. Plasma and dialysate glucose levels were determined by a glucose oxidase method [13]. Ethanol in the dialysate was analysed by a fluorometric method [14]. Plasma-free insulin was determined by radioimmunoassay, using a commercial kit (Pharmacia, Uppsala, Sweden). Catecholamines were analysed by high-performance liquid chromatography with electrochemical detection [15]. 


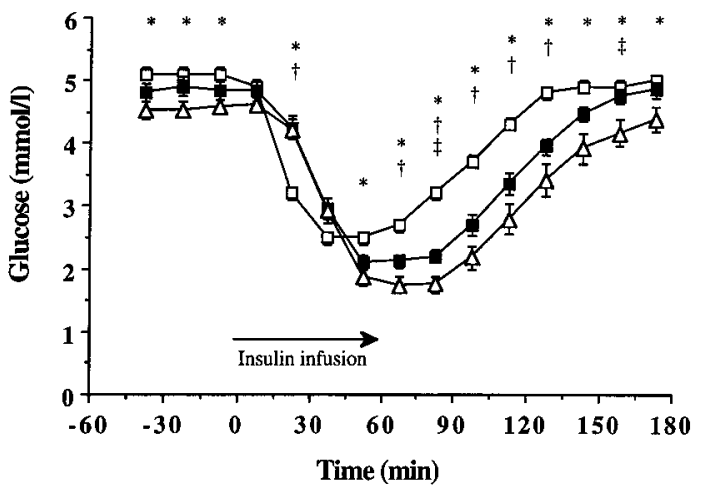

Fig. 1. Glucose levels in arterialized venous plasma $(\square)$, adipose tissue $(\square)$ and skeletal muscle $(\triangle)$ during a hyperinsulinaemic $\left(0.15 \mathrm{U} \cdot \mathrm{kg}^{-1} \cdot \mathrm{h}^{-1}\right)$, hypoglycaemic clamp in 10 normal subjects. Insulin was infused from 0 to $60 \mathrm{~min}$. Microdialysis catheters were inserted in the abdominal subcutaneous adipose tissue and the gastrocnaemius muscle and were perfused at $0.3 \mu \mathrm{l} / \mathrm{min}$. Dialysate was sampled in $15-\mathrm{min}$ fractions. Blood samples were obtained in the middle of each dialysate fraction. Values are means \pm SEM. Significant differences $(p<0.05$ with Fisher's PLSD test and Scheffe's $F$-test, ANOVA) plasma-muscle $(*)$, plasma-adipose tissue $(\dagger)$, adipose tissue-muscle $(\$)$

Statistical analysis. Values are means \pm SEM. Also $95 \%$ confidence intervals are given. The coefficient of variation (CV) was calculated as the standard deviation divided by the mean. Variations over time in the same subject were calculated by one-factor analysis of variance (ANOVA) repeated measurements. Two-factor ANOVA, corrected for repeated measurements, were used to compare the glucose curves in plasma, adipose tissue and muscle. Post-hoc analysis by Fisher's PLSD test and Scheffe's $F$-test was performed for comparison of glucose levels at different times. When the results of both tests were significant at the $95 \%$ level the difference was considered significant. Student's $t$-test for paired measurements was used to compare basal glucose levels, glucose nadirs and periods of time during hypoglycaemia. Since three compartments were being compared, Bonferroni correction of the $p$-value was performed.

\section{Results}

Figure 1 shows the glucose levels in the basal state and during the hypoglycaemic clamp. The glucose curves for plasma, adipose tissue and muscle differed significantly $(p=0.0001)$, tow-factor ANOVA, repeated measurements). During basal conditions (before the insulin infusion), the mean glucose level in plasma was $5.1 \pm 0.1 \mathrm{mmol} / \mathrm{l}$, similar to that in adipose tissue $(4.9 \pm 0.1 \mathrm{mmol} / \mathrm{l})$ and significantly higher than that in muscle $(4.5 \pm 0.1 \mathrm{mmol} / \mathrm{l}, p=0.002)$; $95 \%$ confidence interval for the difference plasma-muscle being 0.3-0.8 $\mathrm{mmol} / \mathrm{l}$. During hypoglycaemia, the difference between the glucose levels in plasma and muscle increased to approximately $1.5 \mathrm{mmol} / \mathrm{l}$, the levels in muscle being significantly lower than those in plasma from $52.5 \mathrm{~min}$ and during the rest of the experiment ( $p<0.05$ with Fisher's PLSD test and Scheffe's $F$ test). During hypoglycemia, the glucose values in
Table 1. Plasma levels of free insulin and catecholamines and glucose infusion rates during the hypoglycaemic clamp experiment in 10 normal subjects. The glucose infusion rate is calculated as the mean for every $15-\mathrm{min}$ period

\begin{tabular}{rllll}
\hline $\begin{array}{l}\text { Time } \\
(\mathrm{min})\end{array}$ & $\begin{array}{l}\text { Free insulin } \\
(\mathrm{pmol} / \mathrm{l})\end{array}$ & $\begin{array}{l}\text { Adrenaline } \\
(\mathrm{nmol} / \mathrm{l})\end{array}$ & $\begin{array}{l}\text { Norad- } \\
\text { renaline } \\
(\mathrm{nmol} / \mathrm{l})\end{array}$ & $\begin{array}{l}\text { Glucose } \\
\text { infusion rate } \\
\left(\mathrm{mg} \cdot \mathrm{kg}^{-1} \cdot \mathrm{min}^{-1}\right)\end{array}$ \\
\hline-22.5 & $32 \pm 2$ & $<0.3$ & $1.5 \pm 0.1$ & 0 \\
-7.5 & $33 \pm 2$ & $<0.3$ & $1.5 \pm 0.1$ & 0 \\
7.5 & $\times$ & $\times$ & $\times$ & 0 \\
22.5 & $591 \pm 81$ & $0.1 \pm 0.1$ & $1.4 \pm 0.1$ & $0.3 \pm 0.1$ \\
37.5 & $683 \pm 39$ & $2.0 \pm 0.6$ & $2.4 \pm 0.5$ & $3.1 \pm 0.3$ \\
52.5 & $697 \pm 36$ & $3.1 \pm 0.6$ & $2.3 \pm 0.2$ & $3.0 \pm 0.3$ \\
67.5 & $233 \pm 34$ & $3.3 \pm 0.4$ & $2.1 \pm 0.1$ & $3.1 \pm 0.3$ \\
82.5 & $\times$ & $\times$ & $\times$ & $3.0 \pm 0.3$ \\
97.5 & $\times$ & $\times$ & $\times$ & $2.1 \pm 0.3$ \\
112.5 & $35 \pm 2$ & $0.7 \pm 0.1$ & $1.8 \pm 0.1$ & $1.5 \pm 0.3$ \\
127.5 & $\times$ & $\times$ & $\times$ & $0.9 \pm 0.2$ \\
142.5 & $\times$ & $\times$ & $\times$ & $0.3 \pm 0.2$ \\
157.5 & $\times$ & $\times$ & $\times$ & $0.2 \pm 0.1$ \\
172.5 & $\times$ & $\times$ & $\times$ & $0.1 \pm 0.1$ \\
\hline
\end{tabular}

Values are means \pm SEM

adipose tissue were also lower than those in plasma; the difference was statistically significant from 67.5 to $127.5 \mathrm{~min}(p<0.05$ with Fisher's PLSD test and Scheffe's $F$-test). During the entire experiment, the glucose levels in muscle tended to be lower than those in adipose tissue, the difference being statistically significant only at 82.5 and $157.5 \mathrm{~min}(p<0.05$ with Fisher's PLSD test and Scheffe's $F$-test). At $22.5 \mathrm{~min}$, plasma levels were significantly lower than those in both adipose tissue and muscle ( $p<0.05$ with Fisher's PLSD test and Scheffe's $F$-test).

The glucose nadir was significantly lower in muscle $(1.6 \pm 0.1 \mathrm{mmol} / \mathrm{l})$ and adipose tissue $(2.0 \pm 0.1 \mathrm{mmol} /$ 1) than in plasma $(2.4 \pm 0.1 \mathrm{mmol} / \mathrm{l})(p=0.001$ and 0.02 , respectively); $95 \%$ confidence intervals for the differences plasma-muscle and plasma-adipose tissue being $0.4-1.1 \mathrm{mmol} / 1$ and $0.1-0.5 \mathrm{mmol} / 1$, respectively. The difference between glucose nadirs in muscle and adipose tissue were not significant $(p=0.06)$. The decline in glucose from basal values to the nadir in plasma was $2.7 \pm 0.1 \mathrm{mmol} / 1$, in adipose tissue $2.8 \pm 0.1 \mathrm{mmol} / 1$ and in muscle $3.0 \pm 0.1 \mathrm{mmol} / \mathrm{l}$, the difference between plasma and muscle not being significant $(p=0.07)$. The time from starting the insulin infusion to the glucose nadir was increased in muscle $(69 \pm 5 \mathrm{~min})$ and adipose tissue $(57 \pm 2 \mathrm{~min}) \mathrm{com}$ pared to plasma ( $39 \pm 3 \mathrm{~min})(p=0.0004) ; 95 \%$ confidence intervals for the differences plasma-muscle and plasma-adipose tissue being 19-41 $\mathrm{min}$ and 11$25 \mathrm{~min}$, respectively. The periods from the nadir to the time when the glucose level had increased by $2.0 \mathrm{mmol} / \mathrm{l}$ in the respective compartment were similar in plasma (78 $\pm 4 \mathrm{~min})$, adipose tissue (75 \pm $3 \mathrm{~min}$ ) and muscle (74 $\pm 4 \mathrm{~min})$.

Plasma levels of free insulin and catecholamines and glucose infusion rates during the clamp are 


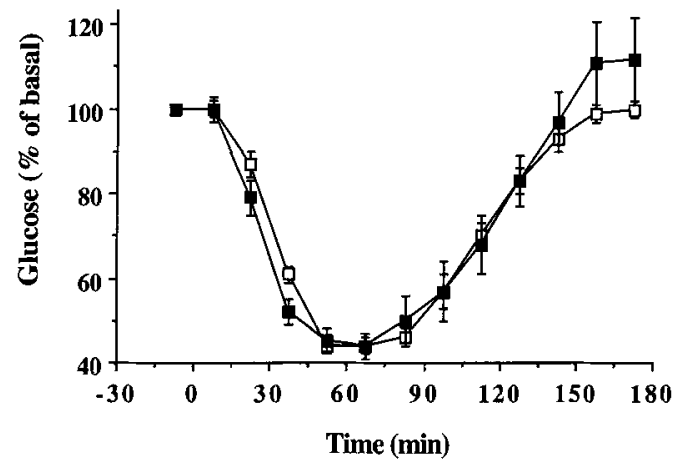

A

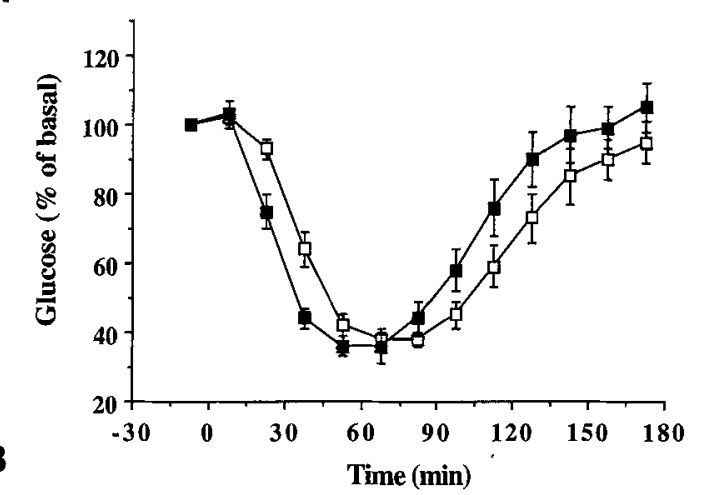

Fig. 2 A, B. Glucose levels in adipose tissue (A) and muscle (B) when the microdialysis catheters were perfused at different flow rates, i.e. $0.3 \mu \mathrm{l} / \mathrm{min}(\square)$ and $2 \mu \mathrm{l} / \mathrm{min}(\square)$. Values are calculated as percentage changes from basal values and given as means \pm SEM of eight experiments

shown in Table 1 . Insulin levels rose to approximately $700 \mathrm{pmol} / \mathrm{l}$ at $37.5-52.5 \mathrm{~min}$, whereafter basal levels were reached at $112.5 \mathrm{~min}$. Plasma adrenaline was not detectable during the basal period and it increased to a maximum at $67.5 \mathrm{~min}$, when plasma glucose levels had started to increase. Plasma noradrenaline increased to maximal levels at $37.5 \mathrm{~min}$ around the time of the plasma glucose nadir.

Figure 2 shows the results where two probes perfused at different velocities $(0.3$ and $2.0 \mu \mathrm{l} / \mathrm{min})$ were compared in adipose tissue and muscle. Perfusion at a higher velocity resulted in lower glucose levels (basal levels in adipose tissue and muscle around 0.9 and $1.5 \mathrm{mmol} / 1$, rèspectively), reflecting a decreased recovery of glucose. Therefore, data are expressed as percentage of basal glucose concentrations, in order to facilitate comparison. The relative glucose changes in adipose tissue and muscle were similar when comparing the two perfusion rates. In adipose tissue, there were no significant differences at any time. In muscle, relative glucose levels were significantly lower at 22.5 and $37.5 \mathrm{~min}$, when perfusing at a higher rate $(p<0.05$ with Fisher's PLSD test and Scheffe's $F$-test). However, later during the experiment the glucose curves were similar. Indeed, the relative glucose levels tended to be higher in the experiment with the higher perfusion velocity.
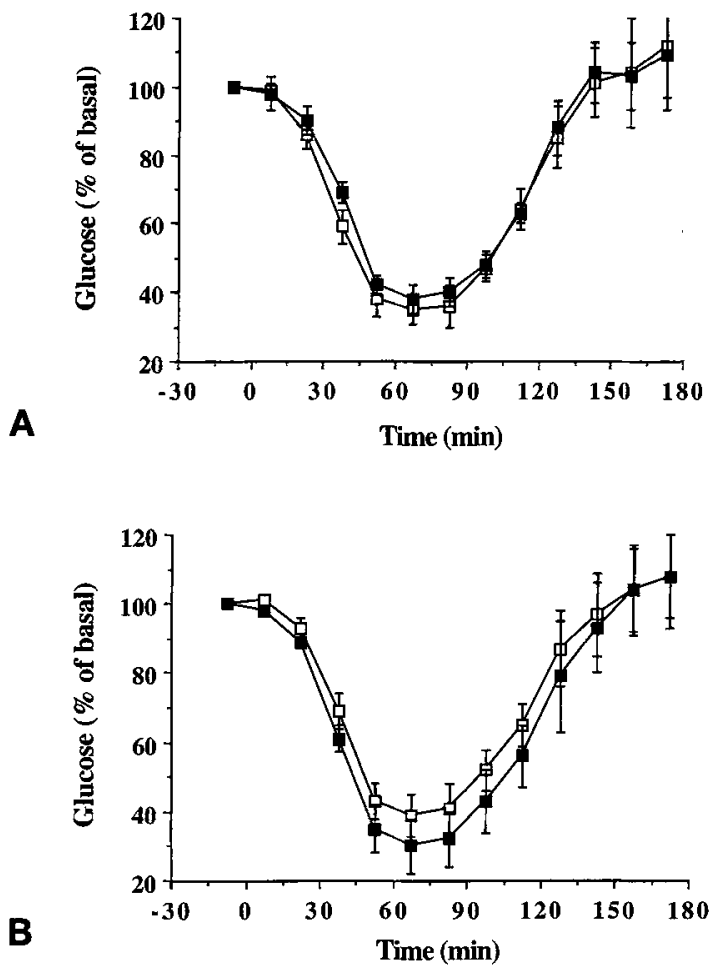

Fig. 3A, B. Glucose levels in adipose tissue (A) and muscle (B) when the microdialysis catheters were perfused by a fluid with glucose $(1 \mathrm{mmol} / \mathrm{l})(\square)$ and without glucose $(\square)$. Values are calculated as percentage changes from basal levels and given as means \pm SEM of four experiments

In four subjects, different perfusion solutions were compared (Fig. 3). The results were similar, whether or not a low glucose concentration was added to the solution.

The in vivo recovery of radiolabelled glucose in adipose tissue and muscle is shown in Figure 4. It was about 90 and $95 \%$ in adipose tissue and muscle, respectively, and remained stable whether or not hydralazine had been added to the tissue perfusate. Without hydralazine the CVs, calculated for each subject, were $1.3-1.9 \%$ and $0.5-1.8 \%$ in adipose tissue and muscle, respectively. With hydralazine the corresponding CVs were $1.6-3.6 \%$ and $0.4-1.5 \%$.

Tissue blood flow was indirectly monitored by the microdialysis-ethanol technique (Fig. 5). In adipose tissue, the ethanol ratio out vs in decreased significantly from $52.5 \mathrm{~min}$ and thereafter $(6-8 \%$ lower compared to basal levels, $p=0.002$ ), reflecting an increase in the nutritive blood flow. In muscle, no significant change in the ethanol ratio was detected.

\section{Discussion}

In the present study glucose levels were significantly lower in adipose tissue and skeletal muscle than in plasma during insulin-induced hypoglycaemia. This finding was most pronounced in skeletal muscle, 


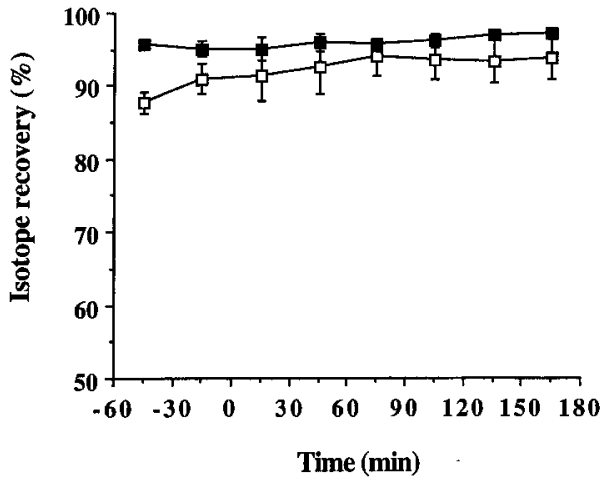

A

\section{B}

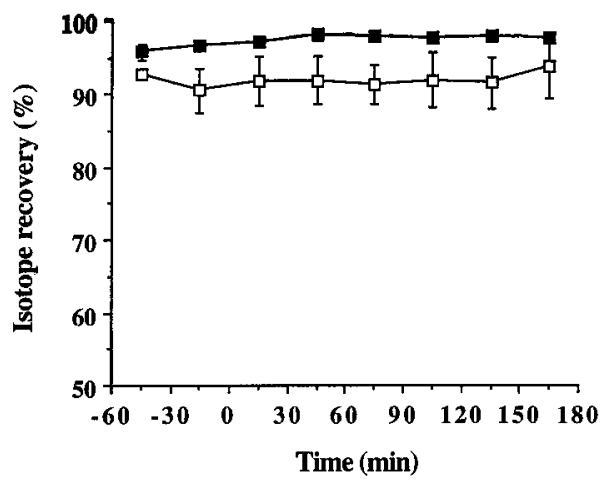

Fig. 4A,B. Isotope recovery of glucose in adipose tissue ( $\square$ ) and muscle ( $)$. Microdialysis catheters were perfused at $0.3 \mu \mathrm{l} / \mathrm{min}$ with a fluid containing ${ }^{14} \mathrm{C}$-glucose. A Ringer's solution only was added to the ${ }^{14} \mathrm{C}$-containing fluid. B Perfusate was supplemented with hydralazine to ensure high and stable blood flow. The recovery was calculated as the ratio of label lost in the tissue vs the total label in the perfusion fluid. Values are means \pm SEM of 3-4 experiments

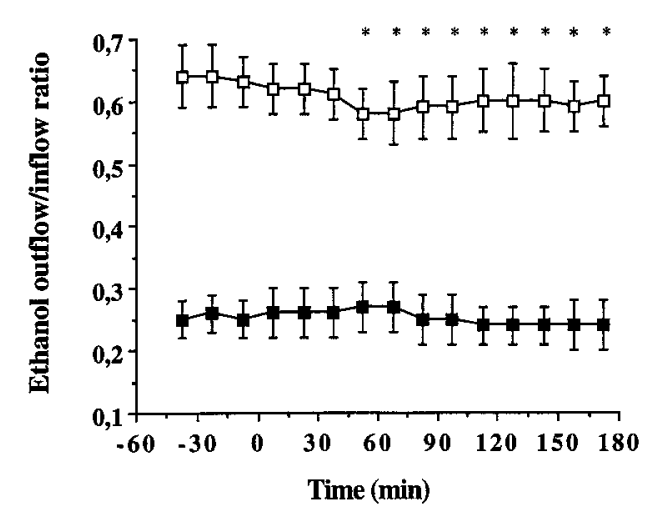

Fig. 5. Variations in the blood flow in adipose tissue $(\square, n=6)$ and muscle $(\square, n=8)$ assessed as the ratio of ethanol in the outgoing vs the ingoing dialysis solvent. Values are means \pm SEM. ${ }^{*} p<0.05$ compared with baseline by one-factor ANOVA

where glucose values during hypoglycaemia were approximately $1.5 \mathrm{mmol} / \mathrm{l}$ lower than the plasma levels. Tissue glucose nadirs were also delayed compared to plasma, which resulted in a markedly protracted glucose fall, especially in muscle. During euglycaemia, muscle values were around $0.5 \mathrm{mmol} / \mathrm{l}$ lower than plasma values, whereas the glucose concentration in adipose tissue was similar to that in plasma, the latter finding being in accordance with several previous studies $[3,4]$.

Direct measurements of the absolute concentration of glucose in human skeletal muscle have not been reported before. By using the "no-net-flux" method for calibration and re-calculation of the in vivo recovery, Müller et al. [7] reported $0.7 \mathrm{mmol} / 1$ lower glucose levels in muscle than in plasma during euglycaemia. Maggs et al. [6] also used this method and found substantially lower values both in adipose tissue and muscle than in plasma during euglycaemia. However, in addition to uncertainty about the accuracy of the indirect calculation of the glucose concentration, a different dialysis membrane was used in the latter study.

There are several reasons why we believe that true glucose values were recorded in the present study. First, the isotope recovery experiments showed a high (>90\%) and stable recovery during the entire study. Secondly, the experiments with different perfusion rates and different perfusion fluids showed that the relative changes in glucose from baseline values were very similar when a sevenfold higher perfusion velocity was used as well as when glucose was added to the perfusion medium. Theoretically, a high perfusion velocity and a pronounced difference in the concentration of the dialysed substance between the perfusion medium and the interstitial fluid could lead to drainage of the substance from the tissue. Thus, our result with various perfusion rates and various perfusion fluids strongly indicate that the low glucose levels in adipose tissue and muscle found in the present study were not due to drainage from the tissues.

It has previously been shown that muscle glucose concentration is blood flow dependent, since an increase of the muscle blood flow increases the glucose levels [10]. In our study, a significant increase in blood flow was recorded during hypoglycaemia in adipose tissue which is in accordance with previous studies using the ethanol technique [16] and the Xenon washout technique [17]. On the other hand, no change in blood flow was detected in muscle. Little information is available about blood flow in skeletal muscle during hypoglycaemia in humans. To our knowledge, only whole limb or forearm flood flow have been determined showing an increase in blood flow $[18,19]$. However, such measurements may include tissues other than muscle and they do not exclusively measure the nutritive blood flow. Hence, as tissue blood flow during hypoglycaemia seems not to be decreased, which would probably cause a decrease in tissue glucose levels, one can conclude that the tissue-plasma glucose differences found in the present study were not due to changes in blood flow. 
The difference between the plasma and tissue glucose concentrations increased until approximately $80 \mathrm{~min}$, at which time the three glucose curves were parallel during the recovery to euglycaemia. Assuming a half-life of plasma insulin of $5 \mathrm{~min}, 80 \mathrm{~min}$ is the approximate time-point when normoinsulinaemia was reached. Thus, we think it likely that hyperinsulinaemia is a prerequisite for the plasma-tissue differences observed during hypoglycaemia and that an increased glucose extraction is the mechanism whereby this relative glucopenia of the tissues occurs. This is in accordance with previous studies where an increased arteriovenous difference was shown during hyperinsulinaemia both in normal subjects and in IDDM patients [20, 21]. In our study, a reduced glucose uptake in muscle and adipose tissue due to catecholamine-induced insulin resistance could also contribute to the parallel glucose curves during the latter part of the experiment. It is also possible that kinetics of insulin may be of importance for the differences in glucose kinetics between plasma and tissues during hypoglycaemia. Thus, the presence of an endothelial barrier for insulin resulting in lower tissue insulin levels and a slower rise of insulin levels in the interstitial fluid compared with plasma has been suggested [2224].

During the initial phase of decline in glucose levels, the levels in plasma were lower than those in adipose tissue and muscle. This contrasts with the results of a previous study which claimed that a decline in adipose tissue glucose may sometimes precede a fall in blood glucose [25]. It was argued that this phenomenon may occur because insulin acts at the tissue level, enabling the tissue glucose to enter the cell and leading to a gradient between tissue and blood glucose concentrations. However, in Sternberg's study, this early tissue glucopenia was seen in only half of the experiments. Furthermore, in addition to the glucose uptake from the tissue, the decreased glucose output from the liver would probably affect the blood-tissue gradient in this hyperinsulinaemic situation. By this mechanism, the decline in glucose in blood would probably precede that in the tissues and thus counteract the glucose-lowering time-lag from tissue to blood caused by glucose uptake in the tissues. In theory, differences in diffusion of glucose may also influence the temporal differences in glucose kinetics between the tissue compartments and blood. However, in the present study, tissue glucose was measured in 15-min fractions and therefore we do not think that conclusions can safely be drawn about blood-tissue gradients during this first phase of rapid decline in the glucose concentration.

The results of the present study may also have clinical implications. The finding of a protracted glucopenia in the peripheral tissues during insulin-induced hypoglycaemia is probably also relevant to IDDM patients. However, in the clinical situation, with subcutaneous administration of insulin, hyperinsulinaemia is sustained and therefore there may be an even more pronounced plasma-tissue difference during iatrogenic hypoglycaemia in IDDM patients. Furthermore, one can speculate whether the protracted glucopenia in muscle in relation to blood during hypoglycaemia may explain the unexpectedly prolonged hypoglycaemias in insulin-treated patients, since the blood-tissue glucose difference may create a demand for glucose in the muscle, resulting in an increased flux of glucose from plasma to the tissues.

In conclusion, this study has shown that there is a relative glucopenia in adipose tissue and skeletal muscle compared to blood during insulin-induced hypoglycaemia, probably due to increased glucose extraction by the tissues. As a result, the restoration of adipose tissue and muscle glucose levels is markedly delayed. Thus, it seems that glucose measurements in adipose tissue and muscle more adequately reflect overall tissue homeostasis than do measurements in blood and that clinically relevant tissue glucopenia may be overlooked by conventional blood glucose measurements.

Acknowledgements. This study was supported by grants from the Swedish Medical Research Council, Swedish Diabetes Associations, Karolinska Institute, Novo Nordisk Pharma AB, the Child Diabetic Foundation and the Foundations of Tore Nilsson, Söderberg, Novo Nordisk, Osterman, Martin Rind and Magnus Bergvall. We also acknowledge the excellent technical assistance of Ms. L.Dungner, Ms. K.Hertel, Ms. BM. Leijonhufvud, Ms. C.Sjöberg, Ms. E. Sjölin and Ms. K. Wåhlén. We thank CMA Microdialysis AB for generous support.

\section{References}

1. Bolinder J, Ungerstedt U, Arner P (1993) Long-term continuous glucose monitoring with microdialysis in ambulatory insulin-dependent diabetic patients. Lancet 342: 10801085

2. Ungerstedt U (1991) Microdialysis - principles and applications for studies in animals and man. J Int Med 230: 365-373

3. Lönnroth P, Jansson P-A, Smith U (1987) A microdialysis method allowing characterization of intercellular water space in humans. Am J Physiol 253: E228-E231

4. Bolinder J, Ungerstedt U, Arner P (1992) Microdialysis measurement of the absolute glucose concentration in subcutaneous adipose tissue allowing glucose monitoring in diabetic patients. Diabetologia 35: 1177-1180

5. Bolinder J, Hagström-Toft E, Ungerstedt U, Arner $\mathbf{P}$ (1997) Self-monitoring of blood glucose in insulin-dependent diabetic patients: comparison with continuous microdialysis measurements of glucose in subcutaneous adipose tissue during ordinary life conditions. Diabetes Care 20: 64-70

6. Maggs DG, Jacob R, Rife F et al. (1995) Interstitial fluid concentrations of glycerol, glucose and amino acids in human quadriceps muscle and adipose tissue. J Clin Invest 96: $370-377$

7. Müller M, Schmid R, Nieszpaur-Los M et al. (1995) Key metabolic kinetics in human skeletal muscle during ischaemia 
and reperfusion: measurement by microdialysis. Europ J Clin Invest 25: 601-607

8. Tossman U, Ungerstedt U (1986) Microdialysis in the study of extracellular levels of amino acids in the rat brain. Acta Physiol Scand 128: 9-14

9. McGuire EAH, Helderman JH, Tobin JD, Andres R, Bergman M (1976) Effects of arterial versus venous sampling on analysis of glucose kinetics in man. J Appl Physiol 41: 565573

10. Hickner RC, Rosdahl H, Borg I, Ungerstedt U, Jorfeldt L, Henriksson J (1991) Ethanol may be used with the microdialysis technique to monitor blood flow changes in skeletal muscle: dialysate glucose concentration is blood flow dependent. Acta Physiol Scand 143: 355-356

11. Lafontan M, Arner P (1996) Application of in situ microdialysis to measure metabolic and vascular responses in adipose tissue. TiPS 17: 309-313

12. Jansson PA, Veneman T, Nurjhan N, Gerich J (1994) An improved method to calculate adipose tissue interstitial substrate recovery for microdialysis studies. Life Sci 21: $1621-1624$

13. Kaddish AH, Little RL, Sternberg JC (1968) A new and rapid method for the determination of glucose by measurement of the rate of oxygen consumption. Clin Chem 14: 116-131

14. Bernst E, Gutman J (1974) Determination of ethanol with alcohol dehydrogenase and NAD. In: Bergmeyer HU (ed) Methods of enzymatic analysis, Vol 3. Verlag Weinheim, pp 1499-1505

15. Hallman H, Farnebo LE, Hamberg B, Jonsson G (1978) A sensitive method for determination of plasma catecholamines using liquid chromatography with electrochemical detection. Life Sci 23: 1049-1052

16. Bolinder J, Sjöberg S, Arner P (1996) Stimulation of adipose tissue lipolysis following insulin-induced hypoglycaemia: evidence of increased beta-adrenoceptor-mediated lipolytic response in IDDM. Diabetologia 39: 845-853

17. Fernquist-Forbes E, Linde B, Gunnarsson R (1988) Insulin absorption and subcutaneous blood flow in normal subjects during insulin-induced hypoglycemia. J Clin Endocrinol Metab 67: 619-623

18. Allwood MJ, Ginsberg J, Paton A (1957) The effect of insulin hypoglycaemia on blood flow in intact and sympathectomized extremities in man. J Physiol 139: 97-107

19. Hilsted J, Bonde-Petersen F, Nørgaard M-B et al. (1984) Haemodynamic changes in insulin-induced hypoglycaemia in normal man. Diabetologia 26: 328-332

20. Liu D, Moberg E, Kollind M, Lins P-E, Adamson U (1991) A high concentration of circulating insulin suppresses the glucagon response to hypoglycemia in normal man. J Clin Endocrinol Metab 73: 1123-1128

21. Liu D, Adamson U, Lins P-E, Kollind M, Moberg E, Andréasson K (1992) Inhibitory effect of circulating insulin on glucagon secretion during hypoglycemia in type 1 diabetic patients. Diabetes Care 15: 56-64

22. Jansson PAE, Fowelin JP, von Schenck HP, Smith UP, Lönnroth PN (1993) Measurement by microdialysis of the insulin concentration in subcutaneous interstitial fluid. Importance of the endothelial barrier for insulin. Diabetes 42: 1469-1473

23. Poulin RA, Steil GM, Moore DM, Ader M, Bergman RN (1994) Dynamics of glucose production and uptake are more closely related to insulin in hindlimb lymph than in thoracic duct lymph. Diabetes 43: 180-190

24. Miles PDG, Levisetti M, Reichart D, Khoursheed M, Moossa AR, Olefsky JM (1995) Kinetics of insulin action in vivo. Identification of rate-limiting steps. Diabetes 44: 947-953

25. Sternberg F, Meyerhoff C, Mennel FJ, Mayer H, Bischof F, Pfeiffer EF (1996) Does a fall in tissue glucose precede a fall in blood glucose? Diabetologia 39: 609-612 